\title{
Comparison of Risk Scoring Systems in HLA-Matched Related Allogeneic Hematopoietic Stem Cell Transplantation: A Retrospective Cohort Study
}

\author{
HLA-Uyumlu Allojenik Hematopoetik Kök Hücre Akraba Nakillerinde Risk Skor Sistemlerinin \\ Kıyaslanması: Retrospektif Kohort Çalışması
}

\author{
(D) Elifcan Aladağ, (D) Haluk Demiroğlu, (D) Yahya Büyükaşık, (D) Hakan Göker \\ Hacettepe University Faculty of Medicine, Department of Hematology, Ankara, Turkey
}

\section{Abstract}

Objective: Allogeneic hematopoietic stem cell transplantation (AHSCT) is a potentially curative treatment of choice for many hematological diseases. However, there are some transplantation-related risks. Predicting the risk-benefit ratio prior to AHSCT facilitates the choice of conditioning regimens and posttransplant follow-up. Hence, many risk models have been developed. The aim of the present study was to compare 6 different risk models that are clinically used.

Materials and Methods: A total of 259 patients were enrolled in this study. The European Society for Blood and Marrow Transplantation (EBMT), Hematopoietic Cell Transplantation Comorbidity Index (HCT-Cl), Age-Adjusted Hematopoietic Cell Transplantation Comorbidity Index (HCT-Cl-Age), revised Pretransplant Assessment of Mortality (rPAM), Acute Leukemia-EBMT (AL-EBMT), and Disease Risk Index (DRI) risk models were applied retrospectively.

Results: The AL-EBMT, HCT-Cl, and HCT-Cl-Age scoring systems were found to be predictive for 2-year overall survival (OS) and 2-year non-relapse mortality (NRM) (2-year OS: AL-EBMT, reference vs. score $8.5-10, H R$ : 1.3, $p=0.035 ; A L-E B M T$, reference vs. score $>10, H R$ : 3.8, $p=0.001$; HCT-Cl: reference vs. score 1-2, HR: 1.4, $p=0.018$; HCT$\mathrm{Cl}$ : reference vs. score $\geq 3, \mathrm{HR}: 2.5, \mathrm{p}<0.001 ; \mathrm{HCT}-\mathrm{Cl}$-Age: reference vs. score 1-2, HR: 1.3, $\mathrm{p}<0.001$; HCT-Cl-Age: reference vs. score $\geq 3$, HR: 3.2, $p<0.001$ ) (2-year NRM: AL-EBMT: reference vs. score 8.5-10, HR: 1.61, $p<0.001$; AL-EBMT: reference vs. score $>10, H R: 3.3, p<0.001$; $\mathrm{HCT}-\mathrm{Cl}$ : reference vs. score 1-2, HR: $1.3, p=0.028 ; \mathrm{HCT}-\mathrm{Cl}$ : reference vs. score $\geq 3, \mathrm{HR}$ : 2.3, $\mathrm{p}=0.011$; HCT-Cl-Age: reference vs. score 1-2, HR: 1.3, $p=0.01$; HCT-Cl-Age: reference vs. score $\geq 3, H R: 2.4, p=0.003$ ). In terms of the Kaplan-Meier estimates of 2-year OS and 2-year NRM, the risk scoring system with the highest predictive power was found to be AL-EBMT (2-year AUC: 0.59 and 0.60, respectively). The other scores were not found to be predictive for 2-year OS and NRM.

Conclusion: In the present study at our bone marrow and stem cell transplant center, it has been demonstrated that the $\mathrm{HCT}-\mathrm{Cl}, \mathrm{HCT}-\mathrm{Cl}-$ Age, and AL-EBMT are good predictors of 2-year NRM and OS.

Keywords: Hematopoietic stem cell transplantation, Risk scoring, Acute leukemia

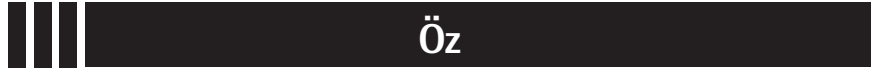

Amaç: Allojeneik hematopoetik kök hücre nakli (AHKHN) birçok hematolojik hastalıkta kullanılan potansiyel küratif bir tedavi seçeneğidir. Bununla birlikte nakil ilişkili bazı riskler bulunmaktadır. AHKHN öncesi risk-fayda oranının belirlenmesi, kullanılacak hazırlık rejimlerinin seçimi ve nakil sonrası hasta takibini kolaylaştırmaktadır. $\mathrm{Bu}$ nedenle birçok risk modeli geliştirilmiştir. Bu çalışmanın amacı, klinik kullanımı olan 6 farklı risk modelini karşılaştırılmasıdır.

Gereç ve Yöntemler: Bu çalışmaya çeşitli hematolojik nedenlerle AHKHN yapılan 259 hasta alınmıştır. Avrupa Kan ve Kemik iliği Nakli Derneği (EBMT), Hematopoetik Hücre Transplantasyon Komorbidite Indeksi (HCT-Cl), yaşa göre düzenlenmiş Hematopoetik Hücre Transplantasyon Komorbidite İndeksi (HCT-Cl-Yaş), düzenlenmiş nakil öncesi mortalite değerlendirme skoru (rPAM), akut lösemi-EBMT skoru (AL-EBMT) ve hastalık risk indeksi (DRI) risk modelleri geriye dönük olarak uygulanmıştır.

Bulgular: $\mathrm{HCT}-\mathrm{Cl}, \mathrm{HCT}-\mathrm{Cl}-\mathrm{Age}$ ve AL-EBMT risk modelleri 2 yıllık genel sağkalım (OS) ve 2 yıllık NRM için prediktif bulundu (2 yıllık OS; AL-EBMT: referans vs skor 8,5-10 HR: 1,3 $\mathrm{p}=0,035$ referans vs skor $>10$ HR: $3,8 p=0,001$, HCT-Cl: referans vs score 1-2 HR: 1,4 p=0,018 referans vs skor $\geq 3$ HR: $2,5 \mathrm{p}<0.001$, HCT-Cl-Age referans vs skor 1-2 HR: 1,3 $p<0,001$ referans vs skor $\geq 3$ HR: 3,2 $p<0,0012$ yıllık NRM: AL-EBMT: referans vs skor 8,5-10 HR: 1,61 $p<0,001$ referans vs skor $>10$ HR: 3,3 $p<0,001$ HCT-Cl: referans vs skor 1-2 HR: 1,3 $p=0,028$ referans vs skor $\geq 3 \mathrm{HR}: 2,3 \mathrm{p}=0,011 \mathrm{HCT}-\mathrm{Cl}$-Age referance vs skor 1-2 HR: 1,3 $p=0,01$ referans vs skor $\geq 3$ HR: 2,4 p=0,003). İki yıllık OS ve 2 yıllık NRM için, prediktif gücü en yüksek olan test AL-EBMT idi (sırasıyla 2 yıllık AUC; 0,59-0,60). Diğer modeller 2 yıllık OS ve NRM için prediktif değildi.

Sonuç: Referans nakil merkezimizde yapılan bu çalışmada, HCT-Cl, $\mathrm{HCT}-\mathrm{Cl}-\mathrm{Yaş}$ ve AL-EBMT risk modellerinin 2 yıllık NRM ve OS için iyi birer belirteç olduğu gösterilmiştir.

Anahtar Sözcükler: Hematopoetik kök hücre nakli, Risk skoru, Akut lösemi

${ }^{\circ}$ Copyright 2021 by Turkish Society of Hematology

Turkish Journal of Hematology, Published by Galenos Publishing House

Address for Correspondence/Yazışma Adresi: Hakan Göker, M.D., Prof., Hacettepe University Faculty of Medicine,

Received/Geliş tarihi: April 17, 2020 Department of Hematology, Ankara, Turkey

E-mail : hgoker1@yahoo.com ORCID: orcid.org/0000-0002-1039-7756 


\section{Introduction}

Allogeneic hematopoietic stem cell transplantation (AHSCT) has been successfully applied as a curative treatment option for many hematological diseases. AHSCT treatment has shown a marked upward trend in the last 20 years [1]. However, this occurred together with an increase in non-relapse mortality (NRM) due to the transplantation. NRM is often related to acute and chronic graft-versus-host disease (GvHD), infections, and transplantation-related toxicities [2]. A decrease in NRM increases the expected overall survival (OS) of patients. Therefore, the selection of a suitable donor and a suitable conditioning regimen to prevent NRM has been a challenge for clinicians [3]. For this purpose, many scoring systems have been developed to evaluate transplantation-related risks. While these predictive risk scores guide clinicians in AHSCT decisions, they also assist in the selection of preparatory regimens and appropriate care after transplantation according to expected risks [4]. These scores can be based on 3 types of systems: a) patient-specific (i.e., CMV serology, donor/recipient age-HLA match, sex match/mismatch, patient comorbidities); b) diseasespecific (i.e., underlying disease, disease status, disease stage, time for transplantation); and c) combined patient-, disease-, and center-specific (experience of the transplantation center) $[4,5]$. A number of retrospective studies have been conducted, especially on 6 different clinical scoring systems $[6,7,8,9,10,11]$. Of these, the Hematopoietic Stem Cell Transplantation Comorbidity Index (HCT-Cl) and its derivative, the HCT-ClAge Index (HCT-Cl-Age), are two scoring systems based on 17 different pretransplant comorbidities of patients. They provide objective and reliable data on the causes of NRM and posttransplant complications based on objective laboratory data and defined morbidities $[7,12]$. The European Society for Blood and Marrow Transplantation (EBMT) scoring is one of the oldest modeled risk scoring systems and EBMT risk groups have been shown to predict 5-year OS and transplant-related mortality $[13,14]$. The Acute Leukemia-EBMT (AL-EBMT) scoring system was first developed in 2015 as a machine-learning algorithm to facilitate clinical decision-making in cases of acute leukemias. These calculations provide a 100-day mortality risk for patients. A validation study also demonstrated its strong predictive features for 2-year OS, leukemia-free survival, and 2-year NRM [15]. For the Pretransplant Assessment of Mortality (PAM) score, the age of the patient, donor type, disease risk, preparation regimens, serum creatinine and alanine aminotransferase levels, and forced expiratory volume in one second (FEV1) and diffusing capacity for carbon monoxide (DLCO) values are used. It has been shown to have significant ability to predict especially 2-year OS. However, not many validation studies have been performed $[16,17]$. A revised PAM (rPAM) scoring system including 5 parameters (age of the patient, donor type, disease risk, FEV1, and patient/recipient CMV serology) was developed in 2015, simplifying the previous one [9]. Another risk assessment model is the Disease Risk Index (DRI). A limited study demonstrated that the DRI risk groups predicted 4-year OS, progression-free survival, incidence of relapse, and NRM, although less effectively so for the last parameter $[18,19]$.

In the present study, we have sought to validate and compare 6 different scoring systems in patients who underwent allogeneic stem cell transplantation in our bone marrow and stem cell transplant center and to demonstrate whether the risk groups predicted 2-year OS and NRM.

\section{Materials and Methods}

All clinical and laboratory data were obtained retrospectively from the electronic medical database system of the Hacettepe University Medical School's Bone Marrow Transplant Center. The study included 259 patients aged 18 years and older who underwent allogeneic stem cell transplantation between 2006 and 2019 from a matched related donor. Patients whose necessary data for the scoring systems (e.g., patient and donor CMV serology, pretransplant disease assessment) were missing were excluded from the study. Conditioning regimens were categorized as defined by Bacigalupo et al. [20] as either myeloablative (MA) or reduced intensity conditioning (RIC) $[21,22]$.

Prognostic scores were calculated for each patient using the definitions provided in the publications of the respective prognostic indices: the EBMT, AL-EBMT, rPAM score, HCT-Cl, HCT$\mathrm{Cl}-\mathrm{Age}$, and DRI. The rPAM score was calculated as per online instructions (http://pamscore.org/) and an online calculator was used for the AL-EBMT score (http://bioinfo.Inx.biu.ac.il/ bondi/ web1.html) [15]. The DRI was not applicable in patients with aplastic anemia, and the AL-EBMT score was applied only for patients with acute leukemia. The EBMT score of the patients was evaluated in 4 risk groups as $0-2,3,4$, and $>5$ [23]. The rPAM score was evaluated in four categories of $<17,17-21$, 21-30, and $>30$ [24]. The HCT-Cl-Age score was evaluated in 3 groups as scores of $0,1-2$, and $>3$ [25]. The 17 comorbidities of the HCT-Cl were assessed as previously defined $[25,26]$. The DRI risk score was analyzed in 4 groups of low, intermediate, high, and very high risk [27]. AL-EBMT scoring was applied according to the expected 100-day mortality value obtained from the online calculator. Patients were divided into 3 risk groups based on 100 -day mortality as $<8.5 \%, 8.5 \%-10 \%$, and $>10 \%$.

\section{Statistical Analysis}

The primary endpoint of the study was NRM, accepted as the period between the $0^{\text {th }}$ day of transplantation and mortality due to any causes other than relapse/progressive disease. The secondary endpoint was OS, accepted as the period from the $0^{\text {th }}$ day of transplantation to mortality due to any reason. All 
analyses were performed using SPSS software (version 20.0; IBM Corp., Armonk, NY, USA).

The 2-year OS ratio of the patients was calculated using Kaplan-Meier curves and the survival difference between the risk groups was compared using the log-rank test. A univariate Cox regression model was used to estimate the impact of the different pretransplant predictive scores on NRM and OS. Cases of $p<0.05$ were considered statistically significant.

C statistics were used to show the possibility of risk groups to predict the endpoints. A C statistical value of 1 represented the highest concordance, while values of less than 0.5 were considered to signify low concordance.

\section{Results}

\section{Patient Characteristics}

Patient characteristics are shown in Table 1. A total of 259 patients were enrolled. The median age of patients at the time of transplantation was 38 years (range: 18 to 64 years). Performance statuses of all patients were low during transplantation. In 3\% of the patients, the Karnofsky performance status was observed to be $<80 \%$. A second AHSCT was performed for 10 patients and all the remaining patients were scored according to the values prior to the first AHSCT. While $48.6 \%$ of the patients had acute myeloid leukemia, $32.4 \%$ had acute lymphocytic leukemia, 7.7\% had chronic myeloid leukemia, 6.9\% had myelodysplastic syndrome, and $4.2 \%$ had non-Hodgkin lymphoma or Hodgkin lymphoma. Transplantations were performed from HLA-matched related donors for all patients. Median follow-up duration after transplantation was 46.6 months. The most common comorbidity was infection (11.9\%), followed by diabetes mellitus (9.2\%). The least seen side effect was psychiatric disorders (1.5\%). Solid tumors and heart valve disease, which have been shown as predictive in HCT-Cl scoring, were not seen in any patients.

\section{Outcomes}

\section{Non-relapse Mortality}

Non-relapse mortality was seen in $8.5 \%$ of patients. The most common causes of NRM were infection $(n=13)$ and acute GvHD (gastrointestinal system GvHD in 2 patients, GvHD and infection in 6 patients). As shown in Table 2, NRM rates were significantly different among the AL-EBMT, HCT-Cl, and HCT-Cl-Age risk groups, and those risk scores were found to be positively predictive for 2-year NRM (AL-EBMT: reference vs. score 8.5-10, HR: 1.61, $p<0.001$; AL-EBMT: reference vs. score $>10, \mathrm{HR}: 3.3, p<0.001$; HCT-Cl: reference vs. 1-2, HR: $1.3, p=0.028 ; \mathrm{HCT}-\mathrm{Cl}$ : reference vs. score $\geq 3, \mathrm{HR}: 2.3, p=0.011$; HCT-Cl-Age: reference vs. score 1-2, HR: 1.3, $p=0.01$; HCT-Cl-Age: reference vs. score $\geq 3$, HR: 2.4, $p=0.003$ ).
The $\mathrm{C}$ statistics of these scoring systems for 2-year NRM were $0.60,0.51$, and 0.52 , respectively. The 2-year NRM calculated with the AL-EBMT was 3.1\%, 14.3\%, and 27\% based on low, intermediate, and high risk, respectively. The 2-year NRM values according to the $\mathrm{HCT}-\mathrm{Cl}$ and $\mathrm{HCT}-\mathrm{Cl}$-Age were $11.2 \%$, $16.2 \%$, and $21.6 \%$ and $4.1 \%, 14.6 \%$, and $21.2 \%$ based on low, intermediate, and high risk, respectively (Table 2).

\section{Overall Survival}

The OS values did not show any statistically significant difference when scores were calculated based on the rPAM, DRI, and EBMT scoring systems. In univariate analysis, AL-EBMT, $\mathrm{HCT}-\mathrm{Cl}$, and $\mathrm{HCT}-\mathrm{Cl}-$ Age risk groups had significant impacts

Table 1. Baseline characteristics of the patient population.

\begin{tabular}{|c|c|}
\hline Characteristics & $\begin{array}{l}\text { Number }(\%) \text { or } \\
\text { Median (range) }\end{array}$ \\
\hline Age (years) & $38(18-64)$ \\
\hline \multicolumn{2}{|l|}{ Diagnosis } \\
\hline Acute myeloid leukemia & $126(48.6)$ \\
\hline Acute lymphoid leukemia & $84(32.4)$ \\
\hline Myelodysplastic syndrome & $18(6.9)$ \\
\hline $\begin{array}{l}\text { Chronic myeloid leukemia } \\
\text { Lymphoma (NHL/HL) }\end{array}$ & $\begin{array}{l}20(7.7) \\
9 / 2(3.4 / 0.7)\end{array}$ \\
\hline Serum creatinine $(\mathrm{mg} / \mathrm{dL})$ & $0.79(0.64-2.3)$ \\
\hline $\begin{array}{l}\text { FEV1 }(\%) \\
\text { Karnofsky performance status } \\
<80 \\
\geq 80\end{array}$ & $\begin{array}{l}90(42-107) \\
12(4.6) \\
247(95.4)\end{array}$ \\
\hline \multicolumn{2}{|l|}{ Conditioning regimen } \\
\hline Myeloablative & $117(45)$ \\
\hline Reduced intensity conditioning & $142(55)$ \\
\hline \multicolumn{2}{|l|}{ CMV serology } \\
\hline Recipient/donor negativity & $36(13)$ \\
\hline Recipient or donor negativity & $30(10)$ \\
\hline Recipient/donor positivity & $223(77)$ \\
\hline Time from diagnosis to AHSCT (months) & $7.7(2-173)$ \\
\hline Sex mismatch & $140(48.8)$ \\
\hline $\begin{array}{l}\text { Male recipient/female donor } \\
\text { Comorbidities }\end{array}$ & $72(27.7)$ \\
\hline Infection & $31(11.9)$ \\
\hline Diabetes mellitus & $24(9.2)$ \\
\hline Cardiac diseases & $18(6.9)$ \\
\hline Hepatic diseases & $11(4.2)$ \\
\hline Pulmonary diseases & $8(3)$ \\
\hline Peptic ulcer & $6(2.3)$ \\
\hline Psychiatric disorders & $4(1.5)$ \\
\hline Renal diseases & $7(2.7)$ \\
\hline
\end{tabular}


on 2-year OS (AL-EBMT: reference vs. score 8.5-10, HR: 1.3, $p=0.035$; AL-EBMT: reference vs. score $>10, H R: 3.8, p=0.001$; HCT-Cl: reference vs. score 1-2, HR: $1.4, p=0.018$; HCT-Cl: reference vs. score $\geq 3, \mathrm{HR}: 2.5, \mathrm{p}<0.001 ; \mathrm{HCT}$-Cl-Age: reference vs. score 1-2, HR: 1.3, $\mathrm{p}<0.001$; HCT-Cl-Age: reference vs. score $\geq 3$, HR: $3.2, p<0.001$ ) (Figure 1). C statistics of these scoring systems for 2-year OS were $0.59,0.52$, and 0.56 , respectively. While OS was not observed in the group with rPAM scores of 17-24, 2-year OS was found to be significantly higher in patients with rPAM scores of 24-30 and $>30$ compared to the reference group (rPAM: reference vs. score 24-30, HR 1.8, $p=0.037$; rPAM: reference vs. score $>30, \mathrm{HR} 3.6, \mathrm{p}=0.012$ ).

\section{Discussion}

The aim of the present study was to test and validate 6 different transplantation risk scores in a patient group. We found high predictive value for 2-year NRM and 2-year OS using the HCT$\mathrm{Cl}, \mathrm{HCT}-\mathrm{Cl}-\mathrm{Age}$, and $\mathrm{AL}-\mathrm{EBMT}$ scores. In our study, the $\mathrm{C}$ statistics for both models were rather low $(<0.65)$, and there was a trend toward better predictive capacity for the AL-EBMT compared with the $\mathrm{HCT}-\mathrm{Cl}$ and $\mathrm{HCT}-\mathrm{Cl}$-Age scores.

The vast majority of risk-based scoring systems are validated with well-defined broad cohorts. Many studies have been published comparing these scoring systems. However, studies generally only evaluate 2 different scores $[8,11,28,29]$. The present study contributes to the literature in terms of applying 6 different scoring systems for the same patients. To the best of our knowledge, there is only one study in the literature that compared more than 3 risk scoring systems [6]. In that study, 8 different scoring systems were evaluated among 528 patients (EBMT, HCT-Cl, Comorbidity-Age, Comorbidity-EBMT, rDRI, PAM, rPAM, and EASIx); among all of them, the models with

\begin{tabular}{|c|c|c|c|c|c|c|c|}
\hline & $\mathbf{n}$ & 2-year OS, \% (95\% Cl) & HR & $\mathbf{p}$ & 2-year NRM (95\% CI) & HR & $\mathbf{p}$ \\
\hline \multicolumn{8}{|l|}{ EBMT } \\
\hline $0-2$ & 135 & $87.2(72-91.2)$ & Reference & & $7.1(6.9-7.3)$ & 1 & \\
\hline 3 & 73 & $78.6(72.2-81.1)$ & $1.1(0.7-1.8)$ & 0.476 & $9.4(7.3-14.6)$ & $1.2(1.1-1.5)$ & 0.272 \\
\hline 4 & 23 & $80.2(52.2-81.4)$ & $1.3(0.5-2.2)$ & 0.673 & $11.1(8-14.1)$ & $1.4(1.1-2.7)$ & 0.284 \\
\hline 5 & 28 & $60.9(55.6-65.6)$ & $1.8(1-3.1)$ & 0.043 & $14.4(11.2-19.1)$ & $2.4(1.4-4.3)$ & 0.001 \\
\hline \multicolumn{8}{|l|}{ AL-EBMT } \\
\hline$<8.5$ & 163 & $81.2(74.1-97.2)$ & Reference & & $3.1(1-5.1)$ & Reference & \\
\hline $8.5-10$ & 23 & $77.4(70.2-81.5)$ & $1.3(0.6-2.7)$ & 0.035 & $14.3(11.6-21.1)$ & $1.6(0.8-3.1)$ & $<0.001$ \\
\hline$>10$ & 24 & $33.1(30.6-36.1)$ & $3.8(2.1-6.7)$ & 0.001 & $27(18-29.1)$ & $3.3(1.9-4.8)$ & $<0.001$ \\
\hline \multicolumn{8}{|l|}{ rPAM } \\
\hline$<17$ & 217 & $84.2(72.1-86.2)$ & Reference & & $9.1(7.7-12.1)$ & Reference & \\
\hline $17-24$ & 14 & $80.2(55.1-79,8)$ & $2(0.9-4.2)$ & 0.056 & $10.2(6.4-16.1)$ & $1.8(0.8-4)$ & 0.109 \\
\hline $24-30$ & 24 & $61.2(52.3-63.4)$ & $1.8(1-3.3)$ & 0.037 & $17.2(4.1-19.2)$ & $1.7(0.9-3.1)$ & 0.055 \\
\hline$>30$ & 4 & $50.1(22.2-57.3)$ & $3.6(1.3-9.9)$ & 0.012 & - & $2.7(1.1-8.7)$ & 0.084 \\
\hline \multicolumn{8}{|l|}{$\mathrm{HCT}-\mathrm{Cl}$} \\
\hline 0 & 175 & $84.2(72.1-86.1)$ & Reference & & $11.2(8.2-14.1)$ & Reference & \\
\hline $1-2$ & 66 & $72.2(59.1-79.9)$ & $1.4(0.9-2.3)$ & 0.018 & $16.2(13-17.2)$ & $1.3(1.2-2.1)$ & 0.028 \\
\hline$\geq 3$ & 18 & $56.2(41.3-57.2)$ & $2.5(1.2-5)$ & $<0.001$ & $24.6(14.6-26.2)$ & $2.3(1.2-4.6)$ & 0.011 \\
\hline \multicolumn{8}{|l|}{ HCT-Cl-A } \\
\hline 0 & 106 & $84.2(76.2-83.3)$ & Reference & & $4.1(1.3-5.2)$ & Reference & \\
\hline $1-2$ & 117 & 71.9 (66.1-79.9) & $1.3(1.03-2.1)$ & $<0.001$ & $14.6(11.1-16.4)$ & $1.3(1.1-2)$ & 0.01 \\
\hline$\geq 3$ & 36 & $49.1(42.3-57.1)$ & $3.2(5.8-3.9)$ & $<0.001$ & $21.2(16.2-24.4)$ & $2.4(1.3-4.4)$ & 0.003 \\
\hline \multicolumn{8}{|l|}{ DRI } \\
\hline Low & 40 & 81.5 (74.2-85.2) & Reference & & $7.4(6.9-8.2)$ & Reference & \\
\hline Intermediate & 174 & $80(62.9-79.1)$ & $1.1(0.6-1.9)$ & 0.68 & $9.1(6.7-13.4)$ & $1.1(0.6-2)$ & 0.31 \\
\hline High & 31 & 65.7 (57.7-71.5) & $1.6(0.8-3.4)$ & 0.11 & 13.5 (12.2-16.2) & $2.3(1.1-4.7)$ & 0.12 \\
\hline Very high & 14 & $47.6(42.8-62.6)$ & $1.7(0.7-4.3)$ & 0.22 & - & - & - \\
\hline \multicolumn{8}{|c|}{$\begin{array}{l}\text { OS: Overall survival, NRM: non-relapse mortality; HR: hazard ratio; Cl: confidence interval; EBMT: European Society for Blood and Marrow Transplantation; AL-EBMT: Acute Leukemia- } \\
\text { EBMT score; rPAM: revised Pretransplant Assessment of Mortality Score; HCT-Cl: Hematopoietic Cell Transplantation Comorbidity Index; HCT-CI-A: Age-Adjusted Hematopoietic Cell } \\
\text { Transplantation Comorbidity Index; DRI: Disease Risk Index. }\end{array}$} \\
\hline
\end{tabular}



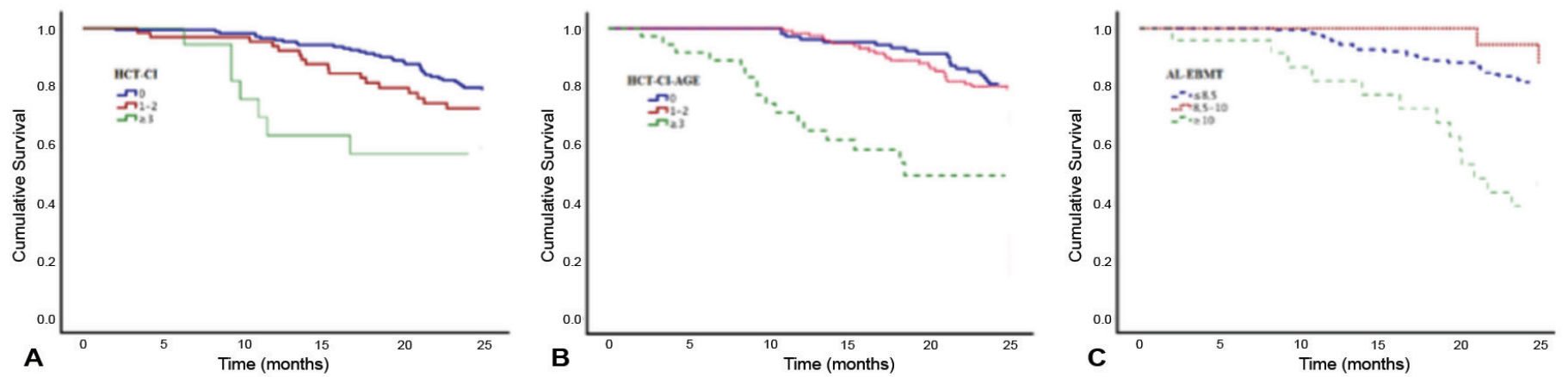

Figure 1. Kaplan-Meier curves of survival in risk groups as defined by HCT-Cl (A), HCT-Cl-Age (B), and AL-EBMT (C).

the highest predictive power for these outcomes were shown to be PAM and rPAM. The PAM score combines patient-, donor-, and disease-related factors. With its update in 2015, replacing DLCO and serum alanine aminotransferase and serum creatinine concentrations with donor/recipient CMV serostatus, the C statistic was similar in the revised and original versions of the PAM scoring system (0.65 versus 0.64$)$ [9]. There are disparate results in the literature for PAM scores. A second study found an association between PAM score and NRM in recipients of MA AHSCT, but not in the subset of reduced intensity recipients, suggesting the lack of utility of the PAM index in patient cohorts with high rates of comorbidities [30,31]. Similarly, we observed that rPAM was predictive for 2-year OS in patients with advanced scores (24-30 and $>30$ ). However, the same trend was not observed for 2-year NRM. This may be a result of the tendency toward RIC in our patients.

In this study, the area under the curve (AUC) value of all scoring systems was found to vary between 0.51 and 0.60 . These values were found to be low, possibly due to the low number of patients or to the abnormal distribution of patients in the risk groups. Since some components of the scores used in this study were the same for all patients, this might have decreased the predictive power of the scoring systems. For example, donor type, which is used in the EBMT score and may be predictive for NRM, was the same for all of our patients (HLA-matched related donors), and this might have reduced the predictivity of the model for NRM [13]. Likewise, we know that seropositive patients receiving grafts from seropositive donors have improved OS compared to seronegative donors if they have received MA conditioning [32]. The $77 \%$ rate of double CMV seropositivity in the patient population may have led to positive selection for the AL-EBMT and rPAM scores. Similarly, the age component was the same in all patients ( $<65$ years) for the rPAM score and matched-related siblings were the donors in all cases, and this caused the majority of patients to be grouped in the low-risk group (score: 17). This might have reduced the predictive power of the rPAM model in this patient group. In addition, this model provides a higher predictive difference in patients undergoing a MA conditioning regimen according to the literature findings. Though subgroup analysis was not performed for patients receiving RIC and MA conditioning regimens, the number of patients transplanted using RIC regimens was observed to be higher.

The novel aspect of this study is that it is a clinical study in which the AL-EBMT model is compared with other scoring systems for the first time. The AL-EBMT score was developed using non-parametric data, unlike all other scoring systems. Although it is predictive for 100-day mortality in patients with acute leukemia, NRM has also been shown to predict leukemia-free survival and 2-year OS. In the validation study performed with 1848 patients in 2017, the hazard ratio of 2-year OS and NRM in intermediate and high risk groups with the reference being the low risk group was 1.3 and 1.24, respectively, and 2.79 and 1.84 , respectively $(p<0.001 ; p=0.029)$ [15]. In the present study, the $\mathrm{C}$ statistics of AL-EBMT revealed that the 2-year predictive power was higher both for OS and NRM than that of all other scores. However, this scoring system can only be applied in patients with acute leukemia and this might be considered a source of bias.

\section{Conclusion}

Six different risk scoring systems used for risk assessment prior to AHSCT for patients referred to a tertiary care transplant center were compared in the present study. The AL-EBMT, $\mathrm{HCT}-\mathrm{Cl}$, and $\mathrm{HCT}-\mathrm{Cl}-$ Age scoring systems were shown to be significantly predictive for 2-year OS and 2-year NRM. These scoring systems are used in many centers since they allow individualized conditioning of the patients for transplantation and guide physicians for better patient follow-up. Future larger multicenter studies are needed to further elucidate the role of these different risk assessment scores and to obtain the most reliable results.

\section{Ethics}

Ethics Committee Approval: The research was approved by the Hacettepe University Ethics Committee (G0 20/1097). 
Informed Consent: As a result of application standards of the hospitals of Hacettepe Medical School, it has been recognized from the patient records that all of the studied patients had given informed consent at the time of hospitalization and before the administration of chemotherapy and other relevant diagnostic/therapeutic standards of care.

\section{Authorship Contributions}

Concept: H.G., H.D.; Design: Y.B.; Data Collection or Processing: Y.B., E.A.; Analysis or Interpretation: E.A.; Writing: E.A.

Conflict of Interest: No conflict of interest was declared by the authors.

Financial Disclosure: The authors declared that this study received no financial support.

\section{References}

1. Singh AK, McGuirk JP. Allogeneic stem cell transplantation: a historical and scientific overview. Cancer Res 2016;76:6445-6451.

2. Fein JA, Shimoni $A$, Labopin $M$, Shem-Tov $N$, Yerushalmi R, Magen $H$, Furie N, Kopel E, Danylesko I, Nagler A, Shouval R. The impact of individual comorbidities on non-relapse mortality following allogeneic hematopoietic stem cell transplantation. Leukemia 2018;32:1787-1794.

3. Gyurkocza B, Sandmaier BM. Conditioning regimens for hematopoietic cell transplantation: one size does not fit all. Blood 2014;124:344-353.

4. Elsawy M, Sorror ML. Up-to-date tools for risk assessment before allogeneic hematopoietic cell transplantation. Bone Marrow Transplant 2016;51:12831300.

5. Potdar R, Varadi G, Fein J, Labopin M, Nagler A, Shouval R. Prognostic scoring systems in allogeneic hematopoietic stem cell transplantation: Where do we stand? Biol Blood Marrow Transplant 2017;23:1839-1846.

6. Shouval R, Fein JA, Shouval A, Danylesko I, Shem-Tov N, Zlotnik M, Yerushalmi R, Shimoni A, Nagler A. External validation and comparison of multiple prognostic scores in allogeneic hematopoietic stem cell transplantation. Blood Adv 2019;3:1881-1890.

7. Sorror ML, Storb RF, Sandmaier BM, Maziarz RT, Pulsipher MA, Maris MB, Bhatia S, Ostronoff F, Deeg HJ, Syrjala KL, Estey E, Maloney DG, Appelbaum FR, Martin PJ, Storer BE. Comorbidity-age index: a clinical measure of biologic age before allogeneic hematopoietic cell transplantation. J Clin Oncol 2014;32:3249-3256.

8. Barba P, Martino R, Perez-Simon JA, Fernandez-Aviles F, Castillo N, Pinana JL, Lopez-Anglada L, Rovira M, Bosch F, Carreras E, Corral LL, Sierra J, Valcarcel D. Combination of the Hematopoietic Cell Transplantation Comorbidity Index and the European Group for Blood and Marrow Transplantation score allows a better stratification of high-risk patients undergoing reducedtoxicity allogeneic hematopoietic cell transplantation. Biol Blood Marrow Transplant 2014;20:66-72.

9. Au BK, Gooley TA, Armand P, Fang M, Madtes DK, Sorror ML, Boeckh MJ, Gibson CJ, Deeg HJ, Storb R, Appelbaum FR, Chien JW, Martin PJ. Reevaluation of the pretransplant assessment of mortality score after allogeneic hematopoietic transplantation. Biol Blood Marrow Transplant 2015;21:848-854.

10. Armand $\mathrm{P}$, Kim HT, Logan BR, Wang Z, Alyea EP, Kalaycio ME, Maziarz RT, Antin JH, Soiffer RJ, Weisdorf DJ, Rizzo JD, Horowitz MM, Saber W. Validation and refinement of the Disease Risk Index for allogeneic stem cell transplantation. Blood 2014;123:3664-3671.

11. Barba P, Pinana JL, Martino R, Valcarcel D, Amoros A, Sureda A, Briones J, Delgado J, Brunet S, Sierra J. Comparison of two pretransplant predictive models and a flexible $\mathrm{HCT}-\mathrm{Cl}$ using different cut off points to determine low-, intermediate-, and high-risk groups: the flexible HCT-Cl is the best predictor of NRM and OS in a population of patients undergoing allo-RIC. Biol Blood Marrow Transplant 2010;16:413-420.

12. Sorror ML, Maris MB, Storb R, Baron F, Sandmaier BM, Maloney DG, Storer B. Hematopoietic cell transplantation (HCT)-specific comorbidity index: a new tool for risk assessment before allogeneic HCT. Blood 2005;106:29122919.

13. Gratwohl A. The EBMT risk score. Bone Marrow Transplant 2012;47:749756.

14. Gratwohl A, Hermans J, Goldman JM, Arcese W, Carreras E, Devergie A, Frassoni F, Gahrton G, Kolb HJ, Niederwieser D, Ruutu T, Vernant JP, de Witte T, Apperley J. Risk assessment for patients with chronic myeloid leukaemia before allogeneic blood or marrow transplantation. Chronic Leukemia Working Party of the European Group for Blood and Marrow Transplantation. Lancet 1998;352:1087-1092.

15. Shouval R, Bonifazi F, Fein J, Boschini C, Oldani E, Labopin M, Raimondi $R$ Sacchi N, Dabash O, Unger R, Mohty M, Rambaldi A, Nagler A. Validation of the acute leukemia-EBMT score for prediction of mortality following allogeneic stem cell transplantation in a multi-center GITMO cohort. Am J Hematol 2017;92:429-434.

16. Parimon $\mathrm{T}, \mathrm{Au} \mathrm{DH}, \mathrm{Martin} \mathrm{PJ}, \mathrm{Chien} \mathrm{JW}$. A risk score for mortality after allogeneic hematopoietic cell transplantation. Ann Intern Med 2006;144:407-414.

17. Mori $Y$, Teshima T, Kamezaki K, Kato K, Takenaka K, Iwasaki H, Miyamoto T, Nagafuji K, Eto T, Akashi K. Validation of pretransplantation assessment of mortality risk score in the outcome of hematopoietic SCT in nonCaucasians. Bone Marrow Transplant 2012;47:1075-1081.

18. Armand P, Gibson CJ, Cutler C, Ho VT, Koreth J, Alyea EP, Ritz J, Sorror ML, Lee SJ, Deeg HJ, Storer BE, Appelbaum FR, Antin JH, Soiffer RJ, Kim HT. A disease risk index for patients undergoing allogeneic stem cell transplantation. Blood 2012;120:905-913.

19. Armand P, Deeg HJ, Kim HT, Lee H, Armistead P, de Lima M, Gupta V, Soiffer RJ. Multicenter validation study of a transplantation-specific cytogenetics grouping scheme for patients with myelodysplastic syndromes. Bone Marrow Transplant 2010;45:877-885.

20. Bacigalupo A, Ballen K, Rizzo D, Giralt S, Lazarus H, Ho V, Apperley J, Slavin S, Pasquini M, Sandmaier BM, Barrett J, Blaise D, Lowski R, Horowitz M. Defining the intensity of conditioning regimens: working definitions. Biol Blood Marrow Transplant 2009;15:1628-1633.

21. Kröger $N$, lacobelli $S$, Franke $G N$, Platzbecker $U$, Uddin $R$, Hübel $K$, Scheid C, Weber T, Robin M, Stelljes M, Afanasyev B, Heim D, Deliliers GL, Onida F, Dreger P, Pini M, Guidi S, Volin L, Günther A, Bethge W, Poiré X, Kobbe G, van Os M, Brand R, de Witte T. Dose-reduced versus standard conditioning followed by allogeneic stem-cell transplantation for patients with myelodysplastic syndrome: a prospective randomized phase III study of the EBMT (RICMAC Trial). J Clin Oncol 2017;35:2157-2164.

22. Abdul Wahid SF, Ismail NA, Mohd-Idris MR, Jamaluddin FW, Tumian N, Sze-Wei EY, Muhammad N, Nai ML. Comparison of reduced-intensity and myeloablative conditioning regimens for allogeneic hematopoietic stem cell transplantation in patients with acute myeloid leukemia and acute lymphoblastic leukemia: a meta-analysis. Stem Cells Dev 2014;23:25352552.

23. Numata A, Tanaka M, Matsumoto $K$, Takasaki H, Tachibana T, Fujimaki $K_{\text {, }}$ Sakai R, Fujisawa S, Tomita N, Fujita H, Maruta A, Ishigatsubo Y, Kanamori $\mathrm{H}$. Validation of the European Group for Blood and Marrow Transplantation (EBMT) risk score in patients receiving allogeneic hematopoietic stem cell transplantation at a single center in Japan. Clin Transplant 2014;28:403-409.

24. Middeke $J M$, Kollinger $F$, Baldauf $H$, Stolzel $F$, Wermke $M$, von Bonin $M$, Sockel K, Link CS, Teipel R, Rollig C, Thiede C, Platzbecker U, Ehninger G, Bornhauser M, Schetelig J. Validation of the Revised Pretransplant Assessment of Mortality Score in patients with acute myelogenous leukemia 
undergoing allogeneic hematopoietic stem cell transplantation. Biol Blood Marrow Transplant 2018;24:1947-1951.

25. Sorror ML, Maris MB, Storb R, Baron F, Sandmaier BM, Maloney DG, Storer B. Hematopoietic cell transplantation (HCT)-specific-comorbidity index: A new tool for risk assessment before allogeneic HCT. Blood 2005;106:29122919.

26. Charlson ME, Pompei P, Ales KL, MacKenzie CR. A new method of classifying prognostic comorbidity in longitudinal studies: development and validation. J Chronic Dis 1987;40:373-383.

27. Armand $P$, Kim $H T$, Logan BR, Wang Z, Alyea EP, Kalaycio ME, Maziarz RT, Antin JH, Soiffer RJ, Weisdorf DJ, Rizzo JD, Horowitz MM, Saber W. Validation and refinement of the Disease Risk Index for allogeneic stem cell transplantation. Blood 2014;123:3664-3671.

28. Xhaard A, Porcher R, Chien JW, de Latour RP, Robin M, Ribaud P, Rocha V, Devergie A, Ferry C, Martin PJ, Socié G. Impact of comorbidity indexes on non-relapse mortality. Leukemia 2008;22:2062-2069.

29. Versluis J, Labopin M, Niederwieser D, Socie G, Schlenk RF, Milpied N, Nagler A, Blaise D, Rocha V, Cornelissen JJ, Mohty M. Prediction of non- relapse mortality in recipients of reduced intensity conditioning allogeneic stem cell transplantation with AML in first complete remission. Leukemia 2015;29:51-57.

30. Barba $P$, Piñana JL, Martino $R$, Valcárcel $D$, Amorós $A$, Sureda $A$, Briones J, Delgado J, Brunet $\mathrm{S}$, Sierra J. Comparison of two pretransplant predictive models and a flexible HCT-Cl using different cut off points to determine low-, intermediate-, and high-risk groups: the flexible $\mathrm{HCT}-\mathrm{Cl}$ is the best predictor of NRM and OS in a population of patients undergoing allo-RIC. Biol Blood Marrow Transplant 2010;16:413-420.

31. Chien JW, Sullivan KM. Carbon monoxide diffusion capacity: How low can you go for hematopoietic cell transplantation eligibility? Biol Blood Marrow Transplant 2009;15:447-453.

32. Ljungman $P$, Brand $R$, Hoek J, de la Camara R, Cordonnier C, Einsele H, Styczynski J, Ward KN, Cesaro S; Infectious Diseases Working Party of the European Group for Blood and Marrow Transplantation. Donor cytomegalovirus status influences the outcome of allogeneic stem cell transplant: a study by the European group for blood and marrow transplantation. Clin Infect Dis 2014;59:473-481. 